\title{
An Investigation on the Digital Addiction of the Students of Faculty of Sports of Kocaeli University
}

\author{
Elif Karagün ${ }^{1 *}$, Zekiye Dilay Ekiz ${ }^{2}$, and Müge Sarper Kahveci ${ }^{2}$ \\ ${ }^{1}$ Faculty of Sports Sciences, Kocaeli University, Umuttepe-Kocaeli, Turkey \\ ${ }^{2}$ Sports Sciences, Institute of Health Sciences, Kocaeli University, Umuttepe-Kocaeli, Turkey
}

\begin{abstract}
The purpose of this study is to investigate the digital addiction levels of the students studying at the Faculty of Sports of Kocaeli University in terms of variables such as their gender, age, school type, parental education level, income status, class level and success level. To this end, following the permission from the faculty administration, the Digital Addiction Scale, developed by Arslan, Kırık, Karaman and Çetinkaya (2015), was administered to a random sample of voluntary students. Data was analyzed by using the SPSS version 25.0. The results showed that digital addiction levels of the students in terms of their gender, age, school type, income level, parental education level, class level and success level were not significant; however, significant differences were found in favor of those who played sports only in class regarding playing sports, and those who attended the evening education regarding type of education programs.
\end{abstract}

\section{Introduction}

Today technological developments are evolving rapidly. The recent developments on artificial intelligence, in particular, have increased the number of new digital devices, and provided them for the needs of humans. Human needs comprise several fields of service including having fun time in sociocultural terms. It is stated that these developments in technology, along with the use of devices such as computers in the fields of entertainment, education etc., have increased the likelihood of the creation of digital usage habit, even the creation of digital addiction [1].

Addiction is defined as a state of people's giving harm to their psycho-physiological health or social life, and a state of irresistible desire to do something over and over again. It is said to be seen in various fields. It is defined as an illness regarding psychological health in the fifth edition of DSM, which stands for Diagnostic and Statistical Manuel of Mental Disorders [2]. Addiction is considered to begin with a constant desire to have a certain object and continue with a constant thought of that object, that is, a constant state of wanting. It is explained that if people cannot get what they want, they believe life will be unbearable. As for addiction in the digital field, it is also pointed out that loss of control

Corresponding author: elif.karagun@gmail.com 
over the use of technology, and excessive and unlimited use of technology cause very serious harm. Internet and technology addiction is defined as a state of deprivation when a person is not able to reach a technological product he is addicted to. When the consequences of technological addiction are considered, it is also stated that it causes attention deficit disorder, hyperactivity, obesity, depression, and sense of loneliness [3]. It is seen that children and young people experience several physical and psychological problems due to their inactive life styles and that they are advised to do activities based on cultural and, in particular, sports activities to cope with these problems. A heavy responsibility lies in the hands of sports trainers, sports managers, physical education and sports teachers and recreation specialists as the ones to take an action against digital addiction and make a habit out of it. Sports is considered to be important to deal with the problems that may be faced due to technology use such as obesity and digital addiction in the future [4-5-6]. It has been an issue of concern to the researchers to determine the addiction levels of the students studying at various departments of the faculties of sports which aim to train them with management, leadership and coaching skills as the future professionals of the sports activities. In this context, it was aimed to carry out a study to determine that. With reference to the question "Do people who study in the fields of profession considered important in coping with digital addiction which is believed to be on the increase today and in the future have digital addiction?", It was aimed to determine the digital addiction levels of the students studying at the Faculty of Sports Sciences of Kocaeli University. It was investigated whether there was a significant difference between the specified addiction levels and the variables such as age, gender, class level, type of education program, income level, parental education level, where they stay, academic success, whether they play sports or not, whether they have a sportsman's license if they do, how long they have been playing that sport, their branch of sports, whether they participate in any activities other than sports, frequency of social media use.

\section{Method}

\subsection{Population and sampling}

This study was carried out as Scanning model, and its population consists of students who are studying Recreation, Coaching Training, Sports Management, Physical Education and Sports Teaching at the Sports Sciences Faculty, Kocaeli University, during the spring term in the Academic year 2017-2018. The sampling of the study consists of 237 volunteering students, who were randomly chosen either in classrooms or training areas or at the canteen, dining hall and several resting areas via "simple random sampling" method after the formal written permission for our study was taken from the school management. Those students were explained the aim of the study first and then they were asked to fill in survey forms.

\subsection{Data collecting tools}

“The Digital Addiction Scale', a 16-item questionnaire developed by [7], was applied to a random sample of voluntary students. This scale was applied to determine the Sports Sciences Faculty students' socio-demographic features such as gender, age, department, grade, education type, economic income, parental education level, the place where their parents have been staying for the last five years, their accommodation as a student, whether they have an access to the internet, whether they do regular sports outside school, their sports branch, and whether they are licenced to do that sport. The Digital Addiction Scale 
has three factors with 29 items. In the scale, which was developed by [7], 4 sub dimensions that are 'gaming', 'social media', 'its effect on the social life', and 'digital addiction' were evaluated [7]. The reliability coefficient of the scale was found as $r=0,92$. The scale reliability Cronbach Alpha coefficient was calculated as 0,847 for our study and this shows that this study is reliable.

\subsection{The analysis of the data}

The data was analysed with SPSS 21.0 package program after the scale applications to the students at Sports Sciences Faculty. Because the data shows a normal dispersion, $t$ test, one of the parametric measurements, was used for the binary clut comparison and ANOVA, another parametric measurement, was used for comparisons more than two clusters. The significance value was taken as 0,05 .

\section{Findings}

Table 1. Frequency and Percentages of the Participants according to their Socio-economic features:

\begin{tabular}{|c|c|c|c|}
\hline \multicolumn{2}{|c|}{ Variables } & $\mathbf{N}$ & $\%$ \\
\hline \multirow[b]{2}{*}{ Gender } & Female & 50 & 21,1 \\
\hline & male & 187 & 78,9 \\
\hline \multirow{5}{*}{ Age } & Aged 16-18 & 7 & 3,0 \\
\hline & Aged 19-21 & 157 & 66,2 \\
\hline & Aged 22-24 & 56 & 23,6 \\
\hline & Aged 25-27 & 12 & 5,1 \\
\hline & Aged 28 and over & 5 & 2,1 \\
\hline \multirow{4}{*}{ Income Level } & 2000£and less & 80 & 33,8 \\
\hline & 2001-2500€ & 66 & 27,8 \\
\hline & 2501-3000€ & 46 & 19,4 \\
\hline & 3001-3500€ & 43 & 18,1 \\
\hline \multirow{4}{*}{ Accommodation type } & State dorm. & 107 & 45,1 \\
\hline & Private dorm. & 18 & 7,6 \\
\hline & Flat with friends & 66 & 27,8 \\
\hline & With family & 46 & 19,4 \\
\hline \multirow{4}{*}{ Mother's education } & Literate & 43 & 18,1 \\
\hline & Primary school & 137 & 57,8 \\
\hline & Secondary school & 43 & 18,1 \\
\hline & University & 14 & 5,9 \\
\hline \multirow{4}{*}{ Father's education } & Literate & 28 & 11,8 \\
\hline & Primary school & 113 & 47,7 \\
\hline & Secondary school & 70 & 29,5 \\
\hline & University & 26 & 11,0 \\
\hline
\end{tabular}

As seen in the Table 1, the experimental group, which consists of 237 students, is made up of 50 women (21.1\%), and 187 men (78, 9\%). Those aged between 16 and 18 are $7(3,0$ $\%)$; those aged between 19 and 21 are 157 ( 66,2\%); those aged between 22 and 24 are 56 ( $23,6 \%)$; those aged between 25 and 27 are $12(5,1 \%)$; and the ones at the age of 28 and over are $5(2,1 \%)$. These people whose income is 2000 tl or less are $80(33,8 \%)$; those who get between $2001 \mathrm{tl}$ and $2500 \mathrm{tl}$ are $66(27,8 \%)$; those who get between 2501 and 3000 tl are $46(19,4 \%)$; and those whose income is 3001 tl and 3500 and over are 43 people $(18,1 \%)$. As for the accommodation types; the answers are as the follows: those who stay at the State dormitory are 107 students $(45,1 \%)$; the number of students staying at private dormitories is $18(7,6 \%)$; Those who share a flat with friends are $66(27,8)$; and finally the 
students who live with their parents are 46 (19, 4 \%). Parental education level results were determined to be as the following: the number of students whose mothers are literate is 43 $(18,1 \%)$; primary school graduates are $137(57,8 \%)$; secondary school graduates are 43 $(18,1 \%)$; and the number of university graduate mothers is $14(5,9 \%)$. As for the fathers' education levels; literate ones are $28(11,8 \%)$; primary school graduates are $113(47,7 \%)$; secondary school graduates are $70(29,5 \%)$; and the number of fathers who are university graduates is $26(11 \%)$.

Table 2. Frequency and Percentages of the Participants according to their education and sports

\begin{tabular}{|l|l|l|l|}
\hline Variables & Formal Education & $\mathbf{N}$ & $\mathbf{\%}$ \\
\cline { 2 - 4 } Education type & Evening Classes & 131 & 55,3 \\
\hline \multirow{4}{*}{ Department } & Physical Education and Sport Teaching & 105 & 45,3 \\
\cline { 2 - 4 } & Coaching & 60 & 25,3 \\
\cline { 2 - 4 } & Recreation & 77 & 32,5 \\
\cline { 2 - 4 } & Sports Management & 30 & 12,7 \\
\hline \multirow{4}{*}{ Grade } & $1^{\text {st }}$ grade & 70 & 29,5 \\
\cline { 2 - 4 } & $2^{\text {nd }}$ grade & 112 & 47,3 \\
\cline { 2 - 4 } & $3^{\text {rd }}$ grade & 71 & 30 \\
\cline { 2 - 4 } & $4^{\text {th }}$ grade & 22 & 9,3 \\
\hline \multirow{3}{*}{$\begin{array}{l}\text { Hoing sports } \\
\text { media }\end{array}$} & Only at school, in classes & 32 & 13,5 \\
\cline { 2 - 4 } & Outside school, non-professionally & 50 & 21,1 \\
\cline { 2 - 4 } & Outside school, professionally (licenced) & 140 & 59,1 \\
\hline & Less than 1 hour & 46 & 19,4 \\
\cline { 2 - 4 } & $1-2$ hours & 11 & 4,6 \\
\cline { 2 - 4 } & $3-4$ hours & 75 & 31,6 \\
\cline { 2 - 4 } & $5-6$ hours & 31 & 34,2 \\
\cline { 2 - 4 } & More than 6 hours & 32 & 13,5 \\
\hline \multirow{3}{*}{$\begin{array}{l}\text { Whether s/he has a hobby } \\
\text { except for sport }\end{array}$} & Yes & 125 & 52,7 \\
\cline { 2 - 4 } & No & 107 & 45,1 \\
\hline
\end{tabular}

When Table 2 was examined, the dispersion of frequency and percentage according to Education type variables is $55,3 \%$ for the formal education and the number for evening classes is $105(45,3 \%) .25,3 \%$ of those students are at Physical Education and Sport Teaching; $32,5 \%$ of them are at Coaching; $12,7 \%$ of them are at Recreation; and 25,3\% of them are at Sport Management. As for their grades variable; 1 st grade students are 47,3\%; 2nd grade students are $30 \%$; 3rd graders are 9,5\%; and 4 th graders are $13,5 \%$.

For the variable 'whether they do any sport or not', the results were determined as the follows: non-professionally sport doers are 59,1\%; sport doers only in classes are $21,1 \%$; and professional and licenced sport doers are 19,4\%. For the variable 'how often they use the social media', the results were like this: those who spend 3 or 4 hours on the social media are $34, \%$; 1 or 2 -hour users are $31,6 \%$; more than 6 -hour users are $16 \%$; the ones who spend 5 or 6 hours on the social media are 13,5\%; and 4,6\% is the result for those who spend less than 1 hour on the social media. For the variable 'participation in any nonsportive activity', 52,7\% of those admitted that they take part in activities. However, 45,1 $\%$ of them stated that they haven't participated in any other activities.

$T$ test results of the digital addiction levels of the participants regarding their sociodemographic features were given in Table 3. Any significant difference was not found between their average scores in these findings except for gender, a non-sportive activity, education type and game dimensions. There was only a significant difference in education type dimension. $(\mathrm{p}=0,028, \mathrm{p}<0,05)$. 
Table 3. $T$ test results of the digital addiction levels of the participants regarding their sociodemographic features

\begin{tabular}{|c|c|c|c|c|c|c|c|c|c|}
\hline \multirow{2}{*}{\multicolumn{2}{|c|}{ Variables }} & \multicolumn{2}{|c|}{$\begin{array}{l}\text { Gaming } \\
\text { Dimension }\end{array}$} & \multicolumn{2}{|c|}{$\begin{array}{l}\text { Social media } \\
\text { dimension }\end{array}$} & \multicolumn{2}{|c|}{$\begin{array}{lr}\text { Effect } & \text { on } \\
\text { social } & \text { life } \\
\text { dimension } & \end{array}$} & \multicolumn{2}{|l|}{$\begin{array}{l}\text { Digital } \\
\text { Addiction }\end{array}$} \\
\hline & & Me.+St.d. & $\mathrm{P}$ & Me.+St.d. & $\mathrm{P}$ & Me.+St.d. & $\mathrm{P}$ & Me.+St.d. & $\mathrm{P}$ \\
\hline \multirow{2}{*}{ Gender } & Female & $2,67 \pm, 97$ & \multirow{2}{*}{,827 } & $3,19 \pm 0,81$ & 792 & $2,48 \pm 0,88$ & \multirow[t]{2}{*}{0,134} & $2,82 \pm, 66$ & \multirow[t]{2}{*}{, 400} \\
\hline & Male & $2,71 \pm, 89$ & & $3,23 \pm 1,01$ & & $2,73 \pm 1,11$ & & $2,92 \pm, 79$ & \\
\hline \multirow[t]{2}{*}{$\begin{array}{l}\text { Education } \\
\text { type }\end{array}$} & $\begin{array}{l}\text { Formal } \\
\text { educat. }\end{array}$ & $2,50,89$ & \multirow[t]{2}{*}{,028 } & $3,22 \pm 1,03$ & 963 & $2,59 \pm 1,1$ & \multirow[t]{2}{*}{,161 } & $2,84 \pm, 69$ & \multirow[t]{2}{*}{, 163} \\
\hline & $\begin{array}{l}\text { Evening } \\
\text { classes }\end{array}$ & $2,8 \pm, 89$ & & $3,23 \pm, 88$ & & $2,79 \pm 1,1$ & & $2,98 \pm, 68$ & \\
\hline $\begin{array}{l}\text { Non- } \\
\text { sportive } \\
\text { activity }\end{array}$ & Yes & $2,68 \pm, 98$ & ,875 & $3,27 \pm, 76$ & 659 & $3,05 \pm 1,1$ &, 584 & $2,99 \pm, 69$ &, 807 \\
\hline
\end{tabular}

Table 4. ANOVA results of the digital addiction levels of the participants regarding their educational status:

\begin{tabular}{|c|c|c|c|c|c|c|c|c|c|}
\hline \multicolumn{2}{|c|}{ Variables } & \multicolumn{2}{|l|}{$\begin{array}{l}\text { Gaming } \\
\text { Dimension }\end{array}$} & \multicolumn{2}{|c|}{$\begin{array}{l}\text { Social media } \\
\text { dimension }\end{array}$} & \multicolumn{2}{|c|}{$\begin{array}{l}\text { Effect on social } \\
\text { life dimension }\end{array}$} & \multicolumn{2}{|c|}{$\begin{array}{l}\text { Digital Addiction } \\
\text { on }\end{array}$} \\
\hline & & Me.+St.D & $P$ & Me.+St.D & $P$ & Me.+St.D & $P$ & Me. + St.D & $\mathrm{P}$ \\
\hline \multirow{4}{*}{ Depart } & Teaching & $2.66 \pm, 93$ & \multirow{4}{*}{$\begin{array}{l}14 \\
2\end{array}$} & $3.17 \pm 0,95$ & \multirow{4}{*}{$\begin{array}{l}, 79 \\
2\end{array}$} & $2.64 \pm 1,04$ & \multirow{4}{*}{$\begin{array}{l}, 39 \\
8\end{array}$} & $2.87 \pm, 96$ & \multirow{4}{*}{$\begin{array}{l}30 \\
1\end{array}$} \\
\hline & Coaching & $2.56 \pm .83$ & & $3.17 \pm 0,93$ & & $2.54 \pm 1,07$ & & $2.80 \pm, 84$ & \\
\hline & Recreation & $2.64 \pm 1,15$ & & $3.18 \pm 1,34$ & & $2.80 \pm 1,15$ & & $2.88 \pm, 18$ & \\
\hline & $\begin{array}{l}\text { Managemen } \\
t\end{array}$ & $2.90 \pm, 83$ & & $3.32 \pm 0,84$ & & $2.82 \pm 1,07$ & & $3.04 \pm, 85$ & \\
\hline \multirow{4}{*}{ Grade } & $1^{\text {st }}$ grade & $2.69 \pm, 91$ & \multirow{4}{*}{$\begin{array}{l}, 95 \\
2\end{array}$} & $3.08 \pm 1,02$ & \multirow[t]{4}{*}{$\begin{array}{l}08 \\
7\end{array}$} & $2.71 \pm 1,06$ & \multirow{4}{*}{$\begin{array}{l}, 77 \\
0\end{array}$} & $2.86 \pm, 78$ & \multirow{4}{*}{$\begin{array}{l}64 \\
1\end{array}$} \\
\hline & $2^{\text {nd }}$ grade & $2.70 \pm, 90$ & & $3.46 \pm, 85$ & & $2.70 \pm 1,13$ & & $3.00 \pm, 70$ & \\
\hline & $3^{\text {rd }}$ grade & $2.62 \pm, 98$ & & $3.22 \pm, 96$ & & $2.69 \pm 1,0$ & & $2.87 \pm, 81$ & \\
\hline & $4^{\text {th }}$ grade & $2.76 \pm, 87$ & & $3.16 \pm, 98$ & & $2.49 \pm 1,26$ & & $2.85 \pm, 82$ & \\
\hline
\end{tabular}

When the Table 4 was examined, no significant difference was found in the sub dimension 'Digital Addiction' according to the department and grade variables.

Table 5. ANOVA results of the digital addiction levels of the participants regarding their use of social

\begin{tabular}{|c|c|c|c|c|c|c|c|c|c|}
\hline \multirow{2}{*}{\multicolumn{2}{|c|}{ Variables }} & \multicolumn{2}{|c|}{ Gaming Dimension } & \multicolumn{2}{|c|}{$\begin{array}{l}\text { Social media } \\
\text { Dimension }\end{array}$} & \multicolumn{2}{|c|}{$\begin{array}{l}\text { The effect on } \\
\text { sociallife } \\
\text { Dimension }\end{array}$} & \multicolumn{2}{|c|}{ Digital Addiction } \\
\hline & & Me.+St.d. & $\mathrm{P}$ & Me.+St.d. & $\mathrm{P}$ & Me.+St.d. & $\mathrm{P}$ & Me.+St.d. & $\mathrm{P}$ \\
\hline \multirow{3}{*}{$\begin{array}{l}\text { Whether } \\
\mathrm{s} / \text { he does } \\
\text { sports }\end{array}$} & Only in classes & $2.68 \pm, 98$ & \multirow[t]{3}{*}{, 179} & $3.27 \pm, 76$ & \multirow[t]{3}{*}{,441 } & $3.05 \pm 1,1$ & \multirow[t]{3}{*}{, 017} & $2.99 \pm 0,69$ & \multirow[t]{3}{*}{23} \\
\hline & $\begin{array}{l}\text { Non-prof. } \\
\text { outside school }\end{array}$ & $2.76 \pm, 85$ & & $3.19 \pm, 97$ & & $2.65 \pm 1,0$ & & $2.91 \pm 0,77$ & \\
\hline & Prof., Licenced & $2.58 \pm 0,97$ & & $3.27 \pm 1,13$ & & $2.36 \pm 1,0$ & & $2.80 \pm 0,81$ & \\
\hline \multirow{5}{*}{$\begin{array}{l}\text { How often } \\
\text { do you use } \\
\text { social } \\
\text { media? }\end{array}$} & $\begin{array}{l}\text { Less than one } \\
\text { hour }\end{array}$ & $2,34 \pm, 87$ & \multirow[t]{5}{*}{,416 } & $3,50 \pm 1,87$ & \multirow[t]{5}{*}{,003 } & $2,59 \pm 1,0$ & \multirow[t]{5}{*}{,347 } & $2,85 \pm 1,10$ & \multirow[t]{5}{*}{,09 } \\
\hline & $1-2$ hours & $2,74 \pm, 99$ & & $2,94 \pm, 77$ & & $2,50 \pm 1,1$ & & $2,76 \pm, 837$ & \\
\hline & 3-4 hours & $2,61 \pm, 95$ & & $3,22 \pm, 96$ & & $2,75 \pm 1,0$ & & $2,88 \pm, 71$ & \\
\hline & 5-6 hours & $2,78 \pm, 78$ & & $3,23 \pm, 92$ & & $2,66 \pm 1,0$ & & $2,94 \pm, 69$ & \\
\hline & $\begin{array}{l}\text { More than } 6 \\
\text { hours }\end{array}$ & $2,84 \pm, 75$ & & $3,68 \pm, 84$ & & $2,92 \pm, 98$ & & $3,19 \pm, 63$ & \\
\hline
\end{tabular}

ANOVA test results in Table 5 were evaluated according to the participants' sportdoing situations and social media variables. Significant differences were only observed in 
'effect on social life 'dimension $((\mathrm{p}=, 017, \mathrm{p}<0,05)$; 'how often he uses social media' dimension and 'social media' dimension $(\mathrm{p}=, 003, \mathrm{p}<0,05)$

Table 6. ANOVA results of the digital addiction levels of the participants regarding their socio-demographic features

\begin{tabular}{|c|c|c|c|c|c|c|c|c|c|}
\hline \multirow{2}{*}{\multicolumn{2}{|c|}{ Variables }} & \multicolumn{2}{|c|}{$\begin{array}{l}\text { Gaming } \\
\text { Dimension }\end{array}$} & \multicolumn{2}{|c|}{$\begin{array}{l}\text { Social media } \\
\text { Dimension }\end{array}$} & \multicolumn{2}{|c|}{$\begin{array}{l}\text { The effect on social } \\
\text { life Dimension }\end{array}$} & \multicolumn{2}{|c|}{ Digital Addiction } \\
\hline & & $\begin{array}{l}\text { Me.+St. } \\
\text { D }\end{array}$ & $\mathrm{P}$ & Me.+St.D & $\mathrm{P}$ & Me.+St.d & $\mathrm{P}$ & Me.+St.d & $\mathrm{P}$ \\
\hline \multirow{5}{*}{ Age } & $16-18$ & $2,63 \pm, 79$ & \multirow[t]{5}{*}{588} & $2,53 \pm, 97$ & \multirow[t]{5}{*}{,436 } & $2,4 \pm 1,16$ & \multirow[t]{5}{*}{,058 } & $2,53 \pm, 91$ & \multirow[t]{5}{*}{286} \\
\hline & $19-21$ & $2,71 \pm, 93$ & & $3,25 \pm, 91$ & & $2,73 \pm 1,0$ & & $2,94 \pm, 73$ & \\
\hline & $22-24$ & $2,590,87$ & & $3,20 \pm, 90$ & & $2,39 \pm 1,0$ & & $2,78 \pm, 79$ & \\
\hline & $25-27$ & $3,06 \pm, 62$ & & $\begin{array}{l}3,32 \pm 1,6 \\
8\end{array}$ & & $3,23 \pm 1,3$ & & $3,19 \pm, 91$ & \\
\hline & over 28 & $2,7 \pm, 90$ & & $3,21 \pm 1,1$ & & $3,16 \pm 1,2$ & & $2,95 \pm, 96$ & \\
\hline \multirow{4}{*}{$\begin{array}{l}\text { Inc. } \\
\text { level }\end{array}$} & $\begin{array}{l}\text { Less } \\
\text { than } \\
2000 €\end{array}$ & $2.63 \pm, 88$ & \multirow[t]{4}{*}{,490 } & $3.23 \pm 1,1$ & \multirow[t]{4}{*}{,968 } & $2.73 \pm 1,1$ & \multirow[t]{4}{*}{,744 } & $2.89 \pm, 85$ & \multirow[t]{4}{*}{,905 } \\
\hline & $\begin{array}{l}2001- \\
2500 €\end{array}$ & $2.69 \pm, 97$ & & $3.15 \pm, 82$ & & $2.67 \pm 0,95$ & & $2.87 \pm, 69$ & \\
\hline & $\begin{array}{l}2501- \\
3000 €\end{array}$ & $2.64 \pm, 90$ & & $3.26 \pm, 82$ & & $2.65 \pm 0,9$ & & $2.89 \pm, 67$ & \\
\hline & $\begin{array}{l}3001- \\
3500 £\end{array}$ & $2.92 \pm, 87$ & & $3.26 \pm, 96$ & & $2.67 \pm 1,2$ & & $2.99 \pm, 82$ & \\
\hline
\end{tabular}

Table 7. ANOVA results of the digital addiction levels of the participants regarding their sociodemographic features

\begin{tabular}{|c|c|c|c|c|c|c|c|c|c|}
\hline \multirow[t]{2}{*}{ Variables } & & \multicolumn{2}{|c|}{$\begin{array}{l}\text { Gaming } \\
\text { Dimension }\end{array}$} & \multicolumn{2}{|c|}{$\begin{array}{l}\text { Social media } \\
\text { Dimension }\end{array}$} & \multicolumn{2}{|c|}{$\begin{array}{ll}\text { The effect } & \text { on } \\
\text { social } & \text { life } \\
\text { Dimension } & \\
\end{array}$} & \multicolumn{2}{|c|}{$\begin{array}{l}\text { Digital } \\
\text { Addiction }\end{array}$} \\
\hline & & Me.+St.d & $\mathrm{P}$ & Me.+St.d & $\mathrm{P}$ & Me.+St.d & $\mathrm{P}$ & Me.+St.d & $\mathrm{P}$ \\
\hline \multirow{4}{*}{$\begin{array}{l}\text { Mother's } \\
\text { education }\end{array}$} & Literate & $2.59 \pm, 90$ & \multirow[t]{4}{*}{,620 } & $3.28 \pm 1,02$ & \multirow[t]{4}{*}{,477 } & $2.87 \pm 1,1$ & \multirow[t]{4}{*}{,257 } & $2.93 \pm, 82$ & \multirow[t]{4}{*}{, 531} \\
\hline & $\begin{array}{l}\text { Primary } \\
\text { school }\end{array}$ & $2.77 \pm, 95$ & & $3.27 \pm 1,01$ & & $2.67 \pm 1,08$ & & $2.94 \pm, 80$ & \\
\hline & Sec. school & $2.620,84$ & & $3.02 \pm 0,83$ & & $2.67 \pm 1,05$ & & $2.78 \pm, 66$ & \\
\hline & Uni. & $2.64 \pm, 63$ & & $3.12 \pm 0,65$ & & $2.21 \pm, 84$ & & $2.73 \pm, 53$ & \\
\hline \multirow{4}{*}{$\begin{array}{l}\text { Father's } \\
\text { education }\end{array}$} & Literate & $2.63 \pm, 94$ & \multirow[t]{4}{*}{,209 } & $3.06 \pm 0,94$ & \multirow[t]{4}{*}{, 121} & $2.89 \pm 1,11$ & \multirow[t]{4}{*}{,687 } & $2.86 \pm, 87$ & \multirow[t]{4}{*}{, 185} \\
\hline & $\begin{array}{l}\text { Primary } \\
\text { school }\end{array}$ & $2.77 \pm, 93$ & & $3.35 \pm 1,07$ & & $2.68 \pm 1,15$ & & $2.98 \pm, 79$ & \\
\hline & Sec. school & $2.53 \pm, 83$ & & $3.03 \pm 0,81$ & & $2.60 \pm, 94$ & & $2.74 \pm, 64$ & \\
\hline & Uni. & $2.90 \pm, 94$ & & $3.30 \pm 0,85$ & & $2.64 \pm 1,06$ & & $3.01 \pm, 80$ & \\
\hline
\end{tabular}

As seen in table 7, the findings for digital addiction level were found insignificant when the variable, parental education level, was evaluated with ANOVA.

\section{Discussion, result and suggestions}

When the digital addiction scores were studied according to socio-demographic variables, no significant difference was found in any of the sub dimensions of Digital Addiction Scale in terms of gender variable. However, male scores for all sub dimensions were observed to be high. Although no significant differences were found in other studies done in this area, 
there are studies that support our study [8]. Yet, it was observed in some studies that male students' scores were high in 'Gaming Addiction' dimension whereas female students' scores were high in 'Social Media Addiction' dimension. No significant difference was found in 'Negative Effect on Social Life' dimension between girls and boys [9]

It was also found that male students are significantly more addicted to gaming than female students. However, girls are much more addicted to 'Social Media' than boys [10].

When the Literature was examined, it can be said that there are studies which do not match with our study results, showing that women use the internet more intensively compared to men, social stress affects addiction to smart phone usage, men experience less social stress than women and therefore men use their smart phones for social media less than women. These findings can be said not to match with our study results [11].

When the education type was examined, the evening class students' scores for Gaming' dimension of 'Digital Addiction Scale' were found to be significantly higher than those who are at Formal education. This result made us think that studying in evening classes is a factor that increases the addiction to digital platform such as computers, the internet, and smart phones. As there are not studies aiming to find out digital addiction according to Education type, it is advisable to do more detailed studies in this area to obtain more accurate results [11].

When the results of the Digital Addiction Scale were examined in terms of participation in an activity other than sports, no significant findings were found. When literature studies were examined, it is seen that internet usage is negatively affecting the social and psychological development of young people [5]. In addition, it is also seen that not being able to socialise causes social anxiety and this leads to an excessive internet usage [11]. When those comments were taken into consideration, it can be said that every activity, either sportive or non-sportive, done in social environment can eliminate digital addiction and it is the key element for decreasing social anxiety.

It was determined that the Digital Addiction scores of the students at Sports Faculty created no significant difference neither in their departments nor in their grades. The reason why there was no difference is considered that these departments are social and active departments that require practice. When these results were examined, there were no other studies in the Literature examining the Digital Addiction in terms of departments.

When the answers to whether the students' do a sport or not were examined, significant results were obtained in favour of those who participate in any sport only in classes in the 'Effect on Social Media' dimension. Yet, when the Literature was examined, it was considered that social stress leads people to digital platform [11] doing a sportive activity has a great effect on decreasing social anxiety. All this information is taken into consideration, it can be said that social anxiety decreases as a result of doing a sport and therefore self-esteem level increases. Thus, it has a positive effect on social life. When the answers given to the question 'How often do you use social media?' were examined, quite significant results were obtained in favour of those who said more than 6 hours in the 'Social Media' dimension. What is interesting is that the digital addiction scores of those who use less than 1 hour comes the second after 6 hours' social media users. In the third line comes the ones who spend 4 or 5 hours on the social media, and then comes those spending 2 or 3 hours on the social media. Digital Addiction scores were ranked from high to low and these results were found significant. As for the Age, digital addiction scale scores were not found significant. When the studies on this issue in the Literature were examined, the incidence of internet addiction in adolescents was estimated as approximately $11 \%$ in China, $8 \%$ in Greece, and 18,4 in Korea [12].

When the studies on the internet addiction of high school students in Turkey were evaluated, it was found that the prevalence of the internet addiction changes between $6,6 \%$ and $15 \%$ [13-14].It was stated that social stress gets lower as the person gets older, it makes 
a positive effect on self-regulation, and the rate of digital addiction in the elderly such as the use of smart phones decreases [11].Our study results for Digital Addiction scores for income level do not show any significant difference. When the studies done before were examined, the income level is effective on socialising [6].

However, unlike this information, no change in the digital addiction level and income level was observed in our study. This can be explained in a way that the participants are studying at Social departments and that sport has an effect on socialising. That's why; this result was obtained. When the students at Sport Faculty were examined according to their accommodation types; no significant difference was found in the digital addiction scores for staying at dormitories, flats, sharing a house with a friend, staying at a relative's house or living with family. Again, there was no significant difference in Digital Addiction Scale scores in terms of mothers' education level and fathers' education levels.

\section{References}

1. R. Gökler, R. Koçak, Uyuşturucu ve Madde Bağımlılığı. Gaziosmanpaşa Üniversitesi Sosyal Bilimler Araştırmaları Dergisi, 3(1), 89-104, (2008)

2. E. Köroğlu, DSM V Tani Ölçütleri Basvuru Elkitabı. HYB Publishing. Ankara (2014)

3. A.Gurcan, S.Ozhan and R. Uslu Digital Games and Children. Accessed via http://ailetoplum.aile.gov.tr/data/5429366a369dc32358ee2a92/ (2008-November).

4. K.Choi, H.Son, M.Park, J.Han, K.Kim, B.Lee, H.Gwak, Internet overuse and excessive daytime sleepiness in adolescents. Psychiatry and Clinical Neurosciences. 63(4), 455462, (2009)

5. J.Sung, J. Lee, H.M. No, Y.S.Park, E.J. Ahn Associations between the risk of Internet addiction and problem behaviours among Korean adolescents. Korean Journal of Family Medicine. 34(2): 115-122. (2013)

6. H. Şahan, The Role of Sport Activities in Socialising Process on University Students Selçuk University. Social Sciences Institute Public Relations and Introduction unpublished thesis of Doctorate, (2007)

7. A.Arslan., A.Kınık, M.Karaman, A.Çetinkaya. Digital Dependence in High School and University Students. International Symposium on Communication and Literature Research July / August / September - Summer Issue: 8. (2015)

8. M.B. Horzum, T.Ayas, Ö.Çakırbalta, Computer Game Addiction Scale for Children. Turkish Psychological Councelling and Guidance Journal, 3(30), 76-88. (2008)

9. S. Balc1, B.Gülnar. Proficiency of Internet addiction and Internet Addiction Among University Students., Selçuk University Press. 6 (1), p. 5-22. (2009)

10. H.H.Çam, N. Nur, An Examination on the relationship between Internet Addiction Prevalence in Adolescents and Psycho-pathological Symptoms and Obesity, TAF Preventive Medicine Bulletin, TAF Prev Med Bull, 14 (3), 181-188, (2015)

11. J.A.M.Alexander, V.Deursen, C.L.Bolle, S.M.Hegner, P.A.M. Kommers, Modeling Habitual and Addictive Smartphone Behaviour: The role of smartphone usage types, emotional intelligence, social stress, self-regulation, age, and gender. Computers in Human Behavior, 45, 411-420.(2015)

12. Y. Kim, J.Y. Park, S.B.Kim, I.K.Jung, Y.S.Lim, J.H.Kim, The effects of Internet addiction on the lifestyle and dietary behaviour of Korean adolescents. Nutrition Research and Practice, 4, 51-57, (2010) 
13. F.O. Öztürk, M. Ekinci, O. Öztürk, F. Canan.. The relationship of affective temperament and emotional-behavioral difficulties to internet addiction in Turkish teenagers. ISRN Psychiatry. 961734,1-6. 7. (2013)

14. T. Şaşmaz, S. Öner,A.O. Kurt, G. Yapıcı, A.E.Yazıcı, R. Buğdaycı, M.Sis, Prevalence and risk factors of Internet addiction in high school students. European Journal of Public Health. 24(1), 15-20, (2014) 